Article

\title{
The Use of Information and Communications Technology in Vocational Education and Training-Premise of Sustainability
}

\author{
Alecxandrina Deaconu ${ }^{1}$, Elena Mădălina Dedu ${ }^{2}$, Ramona Ștefania Igreț ${ }^{1}$ \\ and Cătălina Radu 1,* (iD) \\ 1 Department of Management, The Bucharest University of Economic Studies, Bucharest 010374, Romania; \\ alex.deaconu@ase.ro (A.D.); ramonaigret@gmail.com (R.S,.I.) \\ 2 Department of Tourism and Hospitality, Technological High School C.A. Rosetti, Constanta 900123, \\ Romania; madalinnad@yahoo.com \\ * Correspondence: catalina.radu@ase.ro; Tel.: +40-723-549-743
}

Received: 7 March 2018; Accepted: 3 May 2018; Published: 8 May 2018

\begin{abstract}
Vocational education and training of human resources in tourism play an important role in the development of the tourism industry and hence in the national, regional and global economy. In this paper, we aimed to analyze the effective use of smart education in the teaching and learning process in tourism. The research was conducted over three academic years (2013-2014, 2014-2015, 2015-2016) in 12 high schools providing tourism specializations in Constanta County, Romania. The main method used was an experiment. Thus, we used information and communication technology (ICT) methods in the educational process (the independent variable) in order to compare students' results to those obtained in control classes, in which only traditional teaching methods were used. The results of our research confirmed our initial hypotheses, namely the fact that by using ICT methods within tourism classes, students understand and assimilate specialised knowledge faster and better, and they form and develop specific skills at a higher level than by using traditional teaching methods. This means that by using the latest technology in classes for teaching and learning disciplines in tourism, it is possible to develop, by the end of the superior cycle of high school, the future qualified human resources required for sustainable tourism.
\end{abstract}

Keywords: vocational education and training; smart education; human resources; competences; sustainable educational process; information and communication technology (ICT)

\section{Introduction}

Tourism has become one of the world's largest and most important industries [1-5] and the role of education as a tool to support sustainable tourism has aquired growing recognition [2]. The premise of this research is that in the tourism industry, more than in other economic sectors, human resources hold a primary role, being the critical factor in the functioning of all the other components of the tourism offering. Education and training represent important keys to success in tourism development and in providing quality travelling and accommodation services. Vocational/professional education and training institutions represent the main element for endowing the new generations with the skills and competences necessary for occupying jobs available in the tourism sector. However, sustainable education in tourism means defining core learning constructs, establishing clear learning goals, and a systems approach to learning design [6]. The incorporation of ICT in such learning activities can be a solution to increasing the students 'engagement and skills [2,7].

Moreover, we were motivated to conduct this research as in Romania the use of new technologies in education is still in its infancy, mainly because of the reluctance of almost all the actors involved 
and a lack of financial resources. We consider that the results of the research can contribute to the general international scientific debate related to introducing new technologies in education. Moreover, the study is meant to acknowledge the role of ICT methods in the development of Romanian tourism students' skills, knowledge and abilities, and to suggest the importance of keeping pace with current technology trends in tourism education.

Despite the increased research interest in tourism, most studies have focused on the analysis of the tourism market, destinations and various indicators (number of visitors, supplying facilities, etc.) rather than on broader issues such as employment in tourism and its influence on people [8,9]. Consequently, there is little empirical evidence to explain the relationship between employment in tourism and economic development, the impact on the informal sector, the status of jobs in this sector, etc.

The attention given to human resources and their employment in tourism tends to fluctuate along with the economic flow of the tourism industry. Thus, in periods of tourism activity decline and increased competition, specialists' attention while participating at international conferences is drawn to the analysis of workforce employment and training in tourism seen as an important creator of jobs. It is well known that the amenity and competitive advantage of touristic destinations do not just rely on their natural and cultural resources, but also on the quality of products and services and, consequently, on the quality of tourism personnel. Research shows that organizations in the tourism industry should adopt different means of encouraging a multi-generational workforce engagement [10]. However, during periods of economic growth in all sectors, including tourism, attention on the employment and human resources in tourism moves to second place.

Issues in the development of human resources in tourism should always be a major topic of concern for researchers in the further development of tourism and related industries, both from an economic and from social and political points of view. Human resources must be considered the key capital of an organization and should not be treated as being just a variable cost [11,12].

In the academic literature, various authors have identified the benefits of using new technologies in the educational process that can also be applied in vocational education and training in tourism [13-19]; however, there are quite a few studies on the use of new technologies in teaching or learning different disciplines in tourism. Thus, the main objective of our paper was to highlight the effectiveness of using information and communication technology (ICT) as a teaching, learning and assessment method, in order to improve the educational process within tourism courses in Romanian high schools.

After this brief introduction into the topic, the research paper highlights the relevant results of previous studies conducted in the tourism education field and the use of ICT as a teaching method in tourism classes. Then, it presents the research methodology of the research. Next, chapters discuss the results of the experiment conducted, through which we could observe the improvements of students' results when using ICT in education, the conclusions, together with the implications, limits of the study, and suggestions for future research.

\section{Theoretical Background}

\subsection{The Role and Importance of Human Resources in Tourism}

Lynch [20] believes that there are some industries in which people are not only important, but rather the key factor for their successful performance. One of them is the tourism industry, in which a company has a direct intangible interface, based on employees' attention to customers [20]. In the tourism and hospitality industry, the focus on intangibles and the human factor are definitely two major global trends [21]. Research shows that the competitive edge will increasingly depend on the human factor and the education, training and development of tourism employees [21]. Moreover, the tourism industry is one of the sectors of the economy where labor turnover is very high. Seasonal activity, short-term contracts or part-time contracts and even low retention [22], even among managers, are reasons taken into consideration when investing or not in human resource-relevant 
training. Solutions are needed to reduce the migration of human resources and to reduce employees' demotivation and staff turnover [23,24].

Service quality in the tourism industry is evaluated by tourism satisfaction, destination competitiveness, organizational and financial performance and, most importantly, human resources [25]. Nowadays, human resources represent a unique, special potential, difficult to imitate and change, that has to be understood, motivated and properly trained in order to achieve organizational objectives [26]. They may be described as the source of human capital used and controlled by an organization, based on direct employment relationships [27]. Obviously, during the last few years, tourism employment has changed at a rapid pace, the main implications for work being related to new skills and service demands, the impact of social media adopting new communication strategies, the pressure to create new jobs, and even the demand for "green" skills [28].

Human resources have two distinct features. The first is made up of the knowledge, competences, and skills of the individuals who are part of an organization, while the second refers to the manner in which individual characteristics are used in order to fulfill their role as employees [29]. Motivated employees are more determined to have a positive and productive behavior [30], and in the tourism industry, education and training are strong motivators [31]. Moreover, a recent study analyzing the impact of various labor force characteristics on labor productivity stated that productivity increased with the capital labor ratio, the proportion of part-time workers, the hours supplied by women immigrants and prime-age workers and, not surprisingly, better educated workers [32].

In addition to tourist potential and the material base, tourism activity requires the presence of human resources for ensuring the functioning of all the other components of the tourism offer. Tourist attractions and facilities have a potential existence until the moment they become tourism products through the human factor [23]. Moreover, tourism service experiences are most of the time intangibles and depend on the interactions between employees and customers [33].

Customer experience is closely linked to the quality of human resources, of those for whom it is not enough to know what to do, but also to know how to be. In order to offer a tourism product, a pleasant natural environment is not enough; it is also necessary to bring life to that product, which involves the addition of interpersonal skills, communication skills, the enjoyment of an irreproachable service, the capacity to meet customers' needs, teamwork skills, and understanding the tourists' expectations [34]. Even in countries where tourism is a new or developing industry, like Laos, businesses show a propensity to pay for training, especially for short-term training, workshops, evening or weekend training [35].

Productivity is determined by the value of products and services (uniqueness, quality), and the efficiency of achieving them. Thus, higher productivity is reflected in higher investment in the development of human resources, efficient allocation of capital, and efficient use of technology. Moreover, productivity is higher at high levels of competition [36,37].

Skills, knowledge and abilities turn the human resources into a valuable and productive tourism asset. The knowledge that employees must have in tourism is an important factor determining the competitiveness of tourist destinations. In order to obtain and enrich this kind of knowledge and skills, educational and research institutions hold a primary role, and, therefore, numerous global training organizations have been created for this purpose.

The World Tourism Organization has encouraged the development of education and research in tourism, establishing an international network of universities specialized in tourism management. This development in education, research and training has determined the appearance of a multitude of articles in academic journals in the tourism domain. Moreover, one of the sustainable development goals emphasized by the World Tourism Organization, SDG 4, is to ensure inclusive and equitable quality education and promote lifelong learning for all in tourism, stating that a skillful workforce is crucial for tourism to prosper [38]. 


\subsection{Vocational Education and Training in Tourism}

The beginning of vocational education and training is found in the period of the emergence of guilds (during the 12th century), when the transfer of information from master to apprentice and the formation of the skills necessary for a certain craft were performed at the workplace, during a period of two to four years, concluding with a specialty examination. The basic models of vocational education and training developed by the middle of the 20th century, with influences over the current vocational/professional education and training systems being: the liberal market economy developed in the United Kingdom; the state-regulated bureaucratic economy initiated in France; and the dual-corporate vocational education and training system developed in Germany [39]. However, Heikkinen [40] emphasizes the fact that this specific form of education has not been a linear and purposeful process, but rather a sequence of different phases and challenges.

The concept of vocational education and training is used to describe the acquisition of knowledge, skills, and competences necessary to attain workplace performance. Vocational education and training represent any type of formal education program that prepares students to get a job in a particular field. The importance of vocational education consists in preparing people for life and in providing the skills required in our society. Economic and social development greatly depends on the development of vocational education/training, because the latter leads to the acquisition of various skills and, therefore, to better access to the labor market.

Vocational education was designed with the aim of training people for a specific profession or vocation, and of endowing students with the skills, knowledge and competences required to obtain a proper job, thus contributing to the performance and competitiveness of future employees. As a leading provider of a skilled workforce, technical and vocational education represent the basis for economic growth worldwide.

The vocational education and training of young people and adults is an important part of the Europe 2020 strategy, with most European countries being concerned about the development of future generations' skills and competences and about their rapid access to the labor market in order to increase competitiveness.

Most companies in tourism face a strong challenge of anticipating the skills that will be needed in the future in the industry under the current conditions of vulnerability and instability. Studies state that in most European countries human resources at all levels in the tourism industry receive little or no industry-relevant training [41], the number of graduates from vocational schools or universities being considered very small in comparison with the size of the industry. Studies indicate that the proportion of employees with university degrees in hospitality management is lower in comparison with all other industries [42].

A study investigating the perceptions and attitudes of tourism students towards working in the tourism industry in Turkey emphasized that the biggest challenge of the industry was to supply and retain a well-educated, well-trained, skilled and engaged workforce [43]. Moreover, other research conducted in China indicated a big gap between the supply and demand for quality personnel in a rapidly growing tourism industry, due to poor curriculum design, educators'qualifications and knowledge and standardisation of education practices [44]. An alarming finding came out from a study conducted in Northern Cyprus where more than $40 \%$ of the undergraduate students were undecided or not willing to work in the industry, which means that the investment in their education was somehow useless for the industry [45]. However, the findings of a study conducted in Indian hotels reveals a strong relationship between employee training and the quality of the services offered [46]. Despite the development and extension of tourism training, there is still a lack of strategic plans and policy guidelines on the development of tourism training and education in many countries $[47,48]$.

Under these circumstances, continuous investment in human resources through participation in training is a key factor of success for tourism organizations worldwide. Improving skills and knowledge can increase the competitiveness of tourist destinations and contribute to the establishment and maintenance of a sustainable industry [49-52]. 
The need to acquire new knowledge and skills is increasingly pressing nowadays, because continuously diversifying tourism offers and services require suitably qualified staff. Thus, human resource training and development play an important role in developing professionalism in the tourism industry. Those workers who permanently acquire new knowledge and skills will excel at work, by attaining higher performance compared to others. Studies state that vocational tourism education have positive effects on performance, profitability, productivity and customer satisfaction [53].

We can observe that European countries confer great importance on human resource training programs for various occupations in tourism. This idea is supported by the high number of secondary-level educational institutions and by their curricula. Vocational education and training in the domain of tourism are based on well-established curricula aimed at acquiring the skills needed in all tourist activities (hotels, restaurants, catering, travelling, transportation, animation, entertainment, etc.), through the use of specific teaching strategies. Moreover, tourism businesses use traineeships and internships to find the most suitable workforce and to provide future candidates with relevant insights from the industry [54].

In their study analyzing sustainability in the tourism and hospitality industry, Baum et al. [55] discussed the importance of education for sustainable tourism, emphasizing the vital role of educators in preparing future employees who can promote sustainability, understand sustainability concepts, and apply them. Their recommendations were to embed practices such as experiential learning, group discussions, collaborative learning, use of social media and other technologies in tourism education in order to stress the importance of sustainability.

\subsection{The Use of Information and Communication Technology (ICT) as a Teaching Method in Tourism Classes}

The tourism industry has been dramatically changed by the development of technology, including social media and ICT [56,57]. The way young tourists search, use, purchase, consume and even influence the development of tourism services is dependent on ICT [58]. Under these circumstances, tourism education and training must take a step forward, keep up with the new trends, and acknowledge that information technology competencies rank nowadays at the top of newly significant competencies, digital literacy being considered as the second form of literacy [16]. The development of new skills, including research and technology, is considered a standard practice in many tourism education programs in the UK [59].

Tourism is a very large industry, and educational programs are addressed to students who have to study a variety of subjects from accounting and tourism to the management of catering establishments. Due to the wide range of topics within this field, sometimes teachers need to use an even wider range of teaching methods compared to their colleagues teaching other disciplines [60].

In order to form students' key competences, teachers need to use new teaching and learning methods that are different from traditional ones. Skills and abilities required in the present and in the future in the tourism industry cannot be learned by teaching a single discipline; more innovative and interdisciplinary approaches are required, such as learning by doing or project-based learning [61-66].

ICT represents a set of tools and techniques used to communicate and to produce, disseminate, preserve and manage the information required in the teaching and learning process. In order to describe the use of computers in the educational process, the concept of "computer-assisted learning" is used quite often. It has been noted that the use of computers in education results in the improvement of students' performance, thereby aiming at promoting not only individualized training, but also cooperative training.

Innovative teaching methods based on active and experiential learning that can be improved by using ICT can increase student engagement and thus improve their results $[67,68]$. However, the inclusion of ICT in education and training is still a challenge in many countries and disciplines, due to the reluctance of teachers [13], insufficient equipment, or traditional way of regarding learning [7].

Research reveals that tourism educators recognize that ICT is vital in exposing students to the challenges of the tourism industry [69]. Still, some authors discuss the fact that in developing countries 
there are major obstacles toward integrating ICT in tourism education like technology anxiety, lack of training, availability of resources, and even the learners' resistance to use their own devices [69]. However, they acknowledge that in secondary tourism education, ICT has the capacity to provide an authentic learning experience, and to enhance students' interest, engagement and motivation to learn. They are a digital generation, meaning that everything related to technology is relevant and interesting [70-72].

In most European countries, the use of ICT in education has become crucial in order to modernize services, to enhance teachers' competences, and to increase students' performance. ICT tools used both in education and in the whole of society are constantly changing, and studies can barely keep up with technology development. However, a sustainable educational process should not only put emphasis on technology, but also look at emotions and methods aimed at improving creativity $[62,63]$.

The number of Internet users worldwide was estimated to 3.58 billion in 2017 and is constantly growing [73]. At the same time, people have easy access to computers, smartphones, tablets, while social networking has become one of the most popular online activities in the world. It is obvious that all these trends will have a direct impact on education, and thus today we speak about thousands of Internet and technology facilities dedicated to education. The recent evolution of the Internet was named Web 2.0 or "read/write Web" and consists of social networking websites, wikis, blogs, social bookmarking, podcasts, and instant messaging [74]. Actual evidence regarding the use of Web 2.0 technologies on learning appears to show that it has a generally positive impact [75]. Web 2.0 technologies for education can be classified according to their functionality-online reflection (blogs, wikis), online collaboration (wikis), social spaces (Facebook, Twitter, Hubs), bookmarking (social bookmarking), 3D immersive virtual worlds (games, social virtual worlds)—and their synchronicity, synchronous tools that permit instant access to feedback and content (Facebook) and asynchronous tools that give more time for reflection (blogs, wikis, social bookmarking) [75].

Web 2.0 technology has been increasingly used to facilitate creativity, information sharing and collaboration between users by social networking websites, wikis, blogs, folksonomies, video-sharing sites, feeds, photo-sharing websites, slide-sharing services, etc.; all these services have led to the emergence and development of web-based communities. While suggesting a new version of the Web, the term Web 2.0 does not refer to the update of the technical specifications, but to changes in the modalities of applications development and in the way people may use the Web [76]. The concept takes into account mainly two important changes. The first refers to migration from the read-only web to a read-write web, including the contents provided by users (participatory web), while the second is so-called cloud computing. Thus, knowledge can be enhanced and also knowledge acquisition becomes easier [77], which to us translates into a more sustainable educational process.

The participatory web means that any private individual, institution, company, school, etc., can easily upload their information on the web, in the form of text, photographs, video or audio [76]. In this way, the Internet has turned into a truly interactive environment, although for many years it had just served as a source of passive consumption of information provided by professionals for users. The new goal of the Internet has become producing and distributing content from all the participants in this extensive network that has developed worldwide. The concept of cloud computing refers to the fact that on Internet servers there are both data and applications that can be accessed by any user from any computer connected to the Internet and equipped with a browser, without installing a particular program on the computer.

Web 2.0 offers many tools that can be successfully used in education and significantly sustain and enhance children's learning [78]. These tools are increasingly used by teachers who have found that Web 2.0 offers real opportunities for teaching and learning [14]. Research suggests that the attitude, personal beliefs and familiarity of teachers with the benefits of using Web 2.0 in education are very important factors in using new technology in teaching [74]. Using Web 2.0 in education implies access to a variety of tools closely related to this concept, such as: wikis; blogs and microblogs; social networks; social bookmarking websites; news feeds (either rich site summary (RSS) or Atom format); 
graphic design services (photo sharing), audio/video (video sharing); software for content creation (Office 2.0), audio and video; or web services for sharing presentations (slide sharing). By using these tools, teachers test and apply new teaching models, and learners need to adapt to the requirements of this new environment in order to take advantage of the latest facilities and opportunities. A study conducted by Palaigeorgiou and Grammatikopoulou suggests that the teachers using Web 2.0 during their classes indicated that, besides enabling more effective learning, Web 2.0 could change the whole education settings, the connection of students with society, and the relationships between schools and society [79].

However, research analyzing the use of Web 2.0 in higher tourism education states that the integration of Web 2.0 means more than just bringing a new educational tool in the field [15]. Web 2.0 means involving students in participating and creating in-depth learning, collaborating, understanding the tools used in the online learning environment, and adapting the final evaluation methods to the new context of learning. Researchers emphasize the fact that Web 2.0 is a radically different way of looking at knowledge and learning [15].

During the educational process, the weblogs and wikis can be easily used in research activities, as are providing web content related to different fields of activity. Nowadays, blogs are valuable sources for taking multiple perspectives on information and for the interpretation of data. Educational applications of wikis can be related to adding, removing or editing content, with students becoming contributors through individual or group editing of content. Wikipedia is one of the most well-known wikis, allowing contributors to clarify content, exchange ideas and search for information.

At first, social networks provided new opportunities to interact with other people. Soon afterwards, social media encompassed tools that allowed publishing, sharing of different images or videos, making plans, cooperating and collaborating. In education the main benefits of social networks are related to engaging students in individual and collaborative learning activities, and also enhancing students learning [80]. However, research highlights the technical challenges associated with the new potential tools used in education related to Web 2.0 and the fact that the workload in learning new digital skills should not be underestimated [80]. Many institutions involved in the educational process are still not prepared with developed systems to support Web 2.0 tools.

Little known educational tools in Romania are the three-dimensional (3-D) immersive virtual worlds. These are interactive environments, sometimes like computer games, that can be accessed by avatars and use different tools that allow users to interact, exchange opinions, and create a space in which the teachers and learners can engage in the social activity of learning [81,82]. Research showed that the main use of 3D immersive virtual worlds in education are for communication spaces, the simulation of space and experiential spaces [82].

Besides Web 2.0 applications, other web-based tools are used to support new teaching and training methods. Research was conducted to examine the effectiveness of the PowToon tool in making business plan presentations [83]. This tool allows users to easily create animated presentations and can be a very useful and attractive tool for students. Besides the fact that the participants were very willing to use animations for their presentation, it also attracted more investment.

\section{Materials and Methods}

\subsection{Research Design}

The main aim of this research was to investigate and demonstrate the effectiveness of using ICT as a teaching, learning and assessment method to improve the educational process in high schools with tourism specializations.

When conducting our research, we also followed a series of objectives related to the educational process:

- Forming and developing students' specific competences by using ICT methods;

- Expanding the knowledge acquired by students during tourism classes; 
- Improving school performances in specialty disciplines, measured through the results obtained in various competitions;

- Increasing students' motivation to actively participate in tourism classes;

- Reducing absenteeism.

In our research, we started from the following hypotheses.

Hypothesis 1 (H1). Specific competences that students form and develop by using ICT methods during tourism classes are superior to those obtained using traditional teaching methods.

Hypothesis 2 (H2). Using ICT methods as teaching methods within tourism classes leads to significant improvements in the degree of conscious understanding and assimilation of specialised knowledge.

The variables used in the research are:

- The continuous and systematic use of ICT methods in the teaching and learning process in tourism, at various educational levels - the independent variable;

- Specific competences, understanding and assimilation of specialised knowledge, which are changing and depending on the independent variable - the dependent variables.

The main method used in the research is the experiment, which consists in dividing the participants into two groups of subjects, respectively the experimental group and the control group, and introducing a change (the independent variable) only to the experimental group, in order to analyze the changes in the dependent variables. In this research, the experiment was to use ICT methods in the educational process (the independent variable) and to compare students' results to those obtained in control classes in which only traditional teaching methods were used.

We used the $t$-test in Microsoft Excel in order to analyze the effects of independent variables on multiple dependent variables, by comparing the results associated with the two levels of the independent variable (using and not using ICT methods in the educational process).

\subsection{Data Collection}

The research was conducted over three academic years (2013-2014, 2014-2015, 2015-2016) in 12 high schools providing tourism specializations in Constanta County, Romania. Following the previous studies, we observed that in Constanta County there are a number of high schools that prepare human resources for the tourism sector, in line with the needs of employers in tourism. Actually, Constanta County is an important tourist area of Romania, where a large part of the country's tourism infrastructure is concentrated, by attracting a large number of tourists every year.

The experiment was organized in four phases, as explained below:

1. The pre-experimental phase-At this stage we performed various activities in order to establish the initial data of our research and the groups to be studied: establishing a good acquaintance of teachers with the subject of our research (ICT methods); elaboration, distribution and interpretation of the questionnaire in order to grasp teachers' opinion on using ICT methods in education; determining the sample content to be used (learning modules and units); creation of groups of students (control classes and experimental classes), approximately equal in terms of knowledge, age, and learning conditions; establishing the initial level of the dependent variables (specific competences and understanding and assimilation of the specialised knowledge in the field of tourism), by measuring their levels in both groups of subjects (experimental and control) by applying the same pre-test.

In the pre-experimental phase of our research, we had 998 participants (50 teachers and 948 students), while in the experimental phase, we had 476 (4 teachers and 472 students).

At the end of this stage, depending on teachers' answers to the questionnaire and on the results obtained by students in the pretest, we selected 4 teachers and 472 students to participate in our experiment, as it can be seen in Table 1. 
There were some challenges in our research when choosing the teachers, as many of them found their participation in the research quite difficult (they did not have access to enough equipment and materials and/or were not used to ICT methods). We have to mention that during the experiment neither the students nor the teachers benefited from training in the ICT tools; the involvement of teachers in the experiment was voluntary.

A totally random design was not possible. Therefore, our main limitations refer to two facts: (1) there were only four teachers that expressed their willingness to participate in the experiment and, thus, only groups of students taught by them could be assessed; and (2) it would have been disruptive in the high schools to rearrange the groups in order to randomize the subjects, and only existing groups were used. Even if we cannot exclude some already-existing differences between groups that might bias our results, we tried to diminish this problem by monitoring the learning process and looking at educational records. Thus, for each of the four teachers, parallel groups of students similar in structure in terms of admission marks in the 9th grade, general learning results until starting our experiment and the main interests of students were selected to participate in the study. Results of all the students from the selected groups were analyzed.

The disciplines taught by the four teachers are Tourism Management, Marketing Research, Operations Management and Finance in Tourism (modules in the tourism specialization). Students' ages ranged from 15 to 18 years old (9th grade-15, 10th grade-16, 11th grade-17, 12th grade-18 years old).

Table 1. Resources involved, pre-experimental phase (1) and experimental phase (2).

\begin{tabular}{|c|c|c|c|c|c|c|}
\hline \multirow{3}{*}{ No. } & \multirow{3}{*}{ High School Name } & \multicolumn{4}{|c|}{ Human Resources } & \multirow{3}{*}{$\begin{array}{c}\text { Material } \\
\text { Resources-ICT }\end{array}$} \\
\hline & & \multicolumn{2}{|c|}{ Teachers } & \multicolumn{2}{|c|}{ Students } & \\
\hline & & Phase 1 & Phase 2 & Phase 3 & Phase 4 & \\
\hline 1 & C.A. Rosetti & 8 & 1 & 193 & 142 & $\begin{array}{l}\text { Tourism laboratory } \\
\text { connected to the Internet }\end{array}$ \\
\hline 2 & Carol I & 8 & - & 114 & - & $\begin{array}{c}\text { Tourism laboratory } \\
\text { connected to the Internet }\end{array}$ \\
\hline 3 & Pontica & 2 & - & - & - & - \\
\hline 4 & Gheorghe Miron Costin & 4 & 1 & 250 & 168 & $\begin{array}{l}\text { Informatics laboratory } \\
\text { connected to the Internet }\end{array}$ \\
\hline 5 & Virgil Madgearu & 3 & 1 & 118 & 50 & $\begin{array}{l}\text { Simulation laboratory } \\
\text { connected to the Internet }\end{array}$ \\
\hline 6 & Jean Dinu, Adamclisi & 3 & - & - & - & - \\
\hline 7 & Dobrogea, Castelu & 4 & 1 & 159 & 112 & $\begin{array}{l}\text { Tourism laboratory } \\
\text { connected to the Internet }\end{array}$ \\
\hline 8 & $\begin{array}{l}\text { Nicolae Dumitrescu, } \\
\text { Cumpăna }\end{array}$ & 2 & - & - & - & - \\
\hline 9 & Carmen Silva & 3 & - & - & - & - \\
\hline 10 & $\begin{array}{c}\text { Economic High School } \\
\text { Mangalia }\end{array}$ & 8 & - & 114 & - & $\begin{array}{l}\text { Simulation laboratory } \\
\text { connected to the Internet }\end{array}$ \\
\hline 11 & Emil Racoviţă, Techirghiol & 3 & - & - & - & \\
\hline \multirow[t]{2}{*}{12} & Ioan N. Roman, Constanţa & 2 & - & - & - & \\
\hline & TOTAL & 50 & 4 & 948 & 472 & \\
\hline
\end{tabular}

2. The experimental phase-We introduced the continuous and systematic use of ICT methods (the independent variable) for teaching and learning in the experimental group, while in the control group the educational process took place as before by using other traditional and modern teaching methods other than ICT. 
Thus, in control classes, various communication methods were used (explanation, description, conversation, instruction, questioning, etc.), exploratory methods (observation, case study, etc.), action methods (exercise, project development, role-playing games, etc.) and other interactive methods.

The activities in the experimental classes were conducted by using ICT methods in teaching and learning of the sample content. The main ICT method used in the experimental sample was the educational platform easyclass.com, in which we created virtual classrooms for all the experimental classes. There were also other ICT tools such as Google (including the Drive), www.classtools.net, creately.com, popplet.com, bubbl.us, edu.glogster.com, padlet.com, cacoo.com, powtoon.com, and lucidchart.com. These teaching tools were introduced at various times of the course in order to either transmit new knowledge or to fix, consolidate or evaluate the previously acquired knowledge. The activities were carried out by teachers who are commonly teaching those classes and who frequently use new technologies in the educational process. The lessons were of different types, in order to achieve well-defined objectives and to attain specific competences in accordance with the professional standards in the field of tourism.

After going through each learning unit included in the sample content of the experiment, other knowledge assessment tests were applied, in both experimental and control classes, which led to a series of results.

3. The post-experimental phase-We were able to measure the dependent variables in both groups by applying the post-test. By using similar methods for testing, we could compare the initial results to those obtained at post-testing, observe the differences, and confirm our research hypotheses.

The dependent variables of the research were:

- $\quad$ specific competences;

- understanding and assimilation of the specialty knowledge.

To measure these two dependent variables, we applied tests to assess knowledge acquired by students in both the experimental classes and the control classes after each learning unit included in the sample content. These tests included items of different types and were made in accordance with the specific knowledge and competences of each unit by following the degree of training and development of pupils in the two samples. Thus, our main data collection instrument consisted in the tests administered for assessment purposes. We consider these tests reliable for assessing the knowledge of students as the teachers involved in the experiment used them every year in order to evaluate the students and improved them constantly.

For example, in the case of C.A. Rosetti High School, the 11th grade, learning unit Marketing Research, the post-test followed the structure presented in Table 2.

Table 2. Post-test description at C.A. Rosetti High School, 11th grade.

\begin{tabular}{cccl}
\hline No. & Item & Score & \multicolumn{1}{c}{ Measured Dependent Variable } \\
\hline 1 & Multiple choice & 15 points $(3 \times 5 \mathrm{p})$ & Understanding and assimilation of specialised knowledge \\
\hline 2 & Fill in blank questions & 15 points $(3 \times 5 \mathrm{p})$ & Understanding and assimilation of specialised knowledge \\
\hline 3 & Matching questions & 15 points $(5 \times 3 \mathrm{p})$ & Understanding and assimilation of specialised knowledge \\
\hline 4 & Dual Choice (True $/$ False $)$ & 10 points $(5 \times 2 \mathrm{p})$ & Understanding and assimilation of specialised knowledge \\
\hline 5 & Fill in blank questions & 10 points $(5 \times 2 \mathrm{p})$ & Understanding and assimilation of specialised knowledge \\
\hline 6 & Structured essay & 25 points $(1 \times 25 \mathrm{p})$ & Specific competences \\
\hline \multicolumn{2}{c}{ Source: authors. }
\end{tabular}

As can be seen, the first five items were used to analyze the specific knowledge acquired, while the sixth focused on the assessment of specific competences. For example, in the same case of the C.A. Rosetti High School 11th grade, learning unit Marketing Research, the specific competences that teachers could assess were (1) capacity to group and synthesize information, (2) critical thinking, (3) written communication, and (4) argumentation. 
Thus, we could compare students' results at the post-test for two parallel groups (one experimental class and one control class). In addition to the assessment test, we had educational records as collection instruments, which have the advantage of following the students' general results over a longer period of time. Therefore, as previously mentioned, making comparisons was possible because parallel groups of students were chosen based on comparable structures in terms of admission marks in the 9th grade, general learning results until starting our experiment and the main interests of students.

Results are presented in Table 3.

Table 3. Students' post-test results at C.A. Rosetti High School, 11th grade.

\begin{tabular}{|c|c|c|c|c|c|c|c|c|}
\hline \multirow{2}{*}{ No. } & \multirow{2}{*}{ Score } & \multirow{2}{*}{ Measured Dependent Variable } & \multicolumn{3}{|c|}{ Score Experimental Group } & \multicolumn{3}{|c|}{ Score Control Group } \\
\hline & & & 9-10 & $7-8.99$ & $5-6.99$ & 9-10 & $7-8.99$ & $5-6.99$ \\
\hline 1 & $\begin{array}{l}15 \text { points } \\
(3 \times 5 p)\end{array}$ & $\begin{array}{l}\text { Understanding and assimilation of } \\
\text { specialised knowledge }\end{array}$ & $57 \%$ & $32 \%$ & $11 \%$ & $28 \%$ & $36 \%$ & $36 \%$ \\
\hline 2 & $\begin{array}{l}15 \text { points } \\
(3 \times 5 p)\end{array}$ & $\begin{array}{l}\text { Understanding and assimilation of } \\
\text { specialised knowledge }\end{array}$ & $57 \%$ & $43 \%$ & - & $12 \%$ & $76 \%$ & $12 \%$ \\
\hline 3 & $\begin{array}{l}15 \text { points } \\
(5 \times 3 p)\end{array}$ & $\begin{array}{l}\text { Understanding and assimilation of } \\
\text { specialised knowledge }\end{array}$ & $48 \%$ & $43 \%$ & $9 \%$ & $12 \%$ & $52 \%$ & $36 \%$ \\
\hline 4 & $\begin{array}{l}10 \text { points } \\
(5 \times 2 p)\end{array}$ & $\begin{array}{l}\text { Understanding and assimilation of } \\
\text { specialised knowledge }\end{array}$ & $53 \%$ & $33 \%$ & $14 \%$ & $16 \%$ & $44 \%$ & $40 \%$ \\
\hline 5 & $\begin{array}{l}10 \text { points } \\
(5 \times 2 p)\end{array}$ & $\begin{array}{l}\text { Understanding and assimilation of } \\
\text { specialised knowledge }\end{array}$ & $50 \%$ & $39 \%$ & $11 \%$ & $12 \%$ & $52 \%$ & $36 \%$ \\
\hline \multicolumn{3}{|c|}{ Average items 1-5 } & \multicolumn{3}{|c|}{12.19} & \multicolumn{3}{|c|}{10.82} \\
\hline \multirow[t]{3}{*}{6} & $\begin{array}{l}25 \text { points } \\
(1 \times 25 p)\end{array}$ & Specific competences & $86 \%$ & $11 \%$ & $3 \%$ & $64 \%$ & $28 \%$ & $8 \%$ \\
\hline & & Average item 6 & & & & & 13.08 & \\
\hline & \multicolumn{2}{|c|}{ Average Romanian mark (1-10) } & \multicolumn{3}{|c|}{8.46} & \multicolumn{3}{|c|}{7.68} \\
\hline
\end{tabular}

We grouped students' results into three categories: $5.00-6.99=$ satisfactory; $7-8.99=$ good; 9.00-10.00 = excellent). We can observe that the average mark is higher for the experimental group (in which ICT methods were used) and students' results are better in terms of both knowledge and specific competences after using these methods.

Also, we appreciate the fact that these methods led to a higher percentage of excellent results, especially if we take into account that in the case of traditional methods the main focus is put on reducing the number of weak results and not necessarily on increasing the number of excellent ones (from satisfactory to good rather than from good to excellent).

The other post-tests have similar results.

4. The retest phase-Through this stage, we could measure the consistency and the durability of the effects of our experiment.

The retest came to reinforce the significance of the results of the post-test for the experimental classes, due to the introduction of the independent variable- the continuous and systematic use of ICT methods in the teaching and learning process in tourism. The results obtained by students from the two groups (experimental and control groups) in the retest phase were similar to those obtained within the post-test stage.

\section{Results}

In order to properly interpret our results, we performed a series of comparative analyses-intergroup and intragroup, qualitative and quantitative.

Through the intergroup analysis, we could compare the results of the experimental and control groups in the two main phases of the research (pre-test and post-test). 
In the pre-test stage, some values were aberrant and data did not follow a normal distribution. This situation led to data adjustments and filtering.

After deciding the final group of students that could be part of the experimental group, in the post-test stage the assumption of normality was ensured (Shapiro-Wilk test) and thus we could use the $t$ test to test if there is a difference between the means of the two samples. Results are presented in Table 4.

Table 4. Intergroup analysis-post-test ( $t$-test: two-sample assuming unequal variances).

\begin{tabular}{ccc}
\hline & Experimental (A) & Control (B) \\
\hline Mean & 8.332727273 & 7.331818182 \\
Variance & 0.064681818 & 0.061036364 \\
Observations & 11 & 11 \\
df & 0 & \\
T Stat & 20 & \\
$\mathrm{P}(\mathrm{T}<=t)$ one-tail & 9.362502155 & \\
$t$ Critical one-tail & $4.73253 \times 10^{-9}$ & \\
$\mathrm{P}(\mathrm{T}<=t)$ two-tail & 1.724718218 & \\
$t$ Critical two-tail & $9.46505 \times 10^{-9}$ & \\
\hline
\end{tabular}

Source: Made by authors.

As can be seen in the above table:

- test statistic > critical value one-tail $(9.36>1.72)$; thus, we reject the null hypothesis and we accept the alternative hypothesis: Mean A > Mean B;

- test statistic > critical value two-tail $(9.36>2.09)$; we reject the null hypothesis in favor of the alternative hypothesis: Mean $A \neq$ Mean $B$.

From the beginning, we set the significance level $\alpha$ to 0.05 . As the P-value was significantly lower, we could reject the null hypothesis in favor of the alternative hypothesis. Using this statistical data analysis procedure shows that the average mark obtained by the students from the experimental group (A) in the post-test is higher than the average mark of the students from the control group (B); thus, we can conclude that the students from the experimental group, after using ICT methods, developed their competences at a higher level compared to their colleagues from the control group, who used other traditional and modern teaching methods. By using ICT methods, teachers managed to adapt more to students' needs and make their courses more attractive to their students.

We also performed an intragroup analysis; intragroup longitudinal comparisons were made and we could observe the evolution of students' performance and, on this basis, highlight the role of ICT methods and techniques in obtaining better results (Table 5). Thus, we should add that students' results increased for both groups (experimental and control), but the increase was significantly higher in the case of the experimental group, for which ICT methods were used, as it can be seen in Figure 1 .

Table 5. Intragroup analysis (pre-test-post-test).

\begin{tabular}{ccc}
\hline & Experimental (A) & Control (B) \\
\hline Average mark (pre-test) & 6.878888889 & 6.826666667 \\
Average mark (post-test) & 8.332727273 & 7.331818182 \\
\hline
\end{tabular}




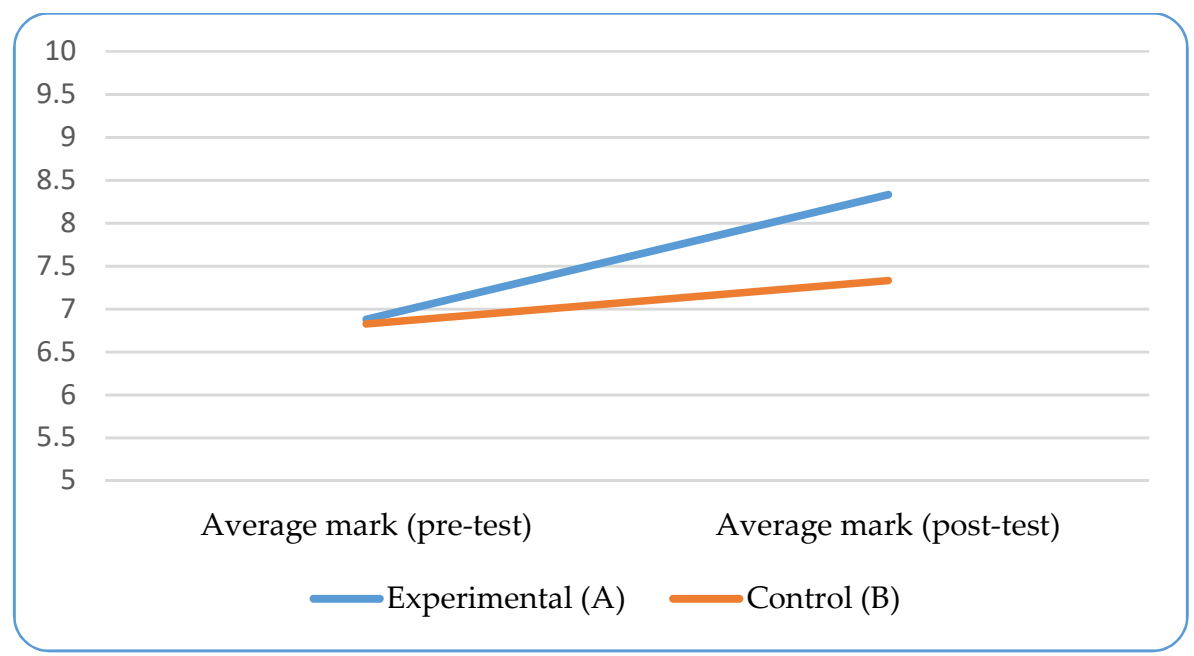

Figure 1. Intragroup analysis (pre-test-post-test).

Our intragroup analysis shows that the post-test results of the students involved in this research were better than pre-test results, which indicates an improvement in the competences development of all the students. At the same time, the comparative analysis demonstrates that the post-test results of the students from the experimental group were better than those obtained by the students from the control group, meaning that the students using ICT methods in the educational process have a higher improvement compared to those of the second group, who used other traditional and modern teaching methods.

Moreover, as we also stated at the end of Section 3, we appreciate the fact that using ICT methods in teaching led to a higher percentage of excellent results, if we take into account that in the case of traditional methods the main focus is generally put on reducing the number of weak results and not necessarily on increasing the number of excellent ones (from satisfactory to good rather than from good to excellent). Of course, this idea should be explored further, since for the moment it is only the result of one experiment conducted over three years in a specific area.

\section{Discussion}

By analyzing the results of our experiment, we could observe a better evolution of the experimental group compared to the control group; students' higher performance in the experimental group is explained by the use of ICT methods and tools in the teaching and learning process in tourism. The results are in line with other studies conducted in the field of education which suggest that ICT has a positive effect over the improvement of teaching and learning $[7,69,84]$.

Different results in the educational process can be caused by various factors such as the learning environment, the teaching styles, the initial level of learners' knowledge, age and level of education, methods used in the teaching and learning process, etc. During this experiment, the only factor that was different between the two groups, and whose influence has been analyzed, referred to the methods used in the educational process. Otherwise, the experiment was carried out in similar classes of students, at the same educational level, having the same age, coming from the same high schools, working in the same laboratories, and being coordinated by the same teachers.

The classes from the control group have been taught by using various traditional and modern teaching-learning methods (except for ICT), while the classes from the experimental group were taught by using ICT methods. Therefore, we could analyze the difference between the results obtained by students from the two groups in the post-experimental phase and, later on, in the retest stage of this research. Taking into consideration the limited prior experience of students with Web 2.0 technologies 
used in education, we can assume that the interest of students also came from the novelty of the teaching approach.

Statistical results obtained by processing data gathered during our investigation confirm our research hypotheses. When using the $t$-test to test the hypothesis that there is no difference between the means of the two samples, we have proved that in the post-test, the average mark obtained by the students from the experimental group was higher than the average mark obtained by the students from the control group.

We believe in these circumstances that the main aim of this research was fully achieved, by demonstrating that the use of ICT as a teaching, learning and assessment method is effective for improving the educational process in tourism courses in high schools. Our research hypotheses were confirmed. Specific competences that students form and develop by using ICT methods during tourism classes are superior to those obtained using traditional teaching methods, and using ICT methods as teaching methods within tourism classes leads to significant improvements in the degree of conscious understanding and assimilation of specialised knowledge. Using virtual classrooms for all the experimental classes and the other ICT tools presented in the experiment proved to increase the students' interest in tourism learning, with students enjoying the ability to experience virtual and simulated classrooms, to receive information through animated presentations, or to use different tools from platforms like classtools.net or edu.glogster.com.

The technology-based way of transmitting the information implies combining the written texts with images, sounds, colors and films that are designed to create attractive and motivating materials for the students that are actively engaged in the learning process. At the same time, by using ICT educational methods, students learn to use various software programs and applications in order to better understand the information they receive, and to also create new useful materials for their learning process. Needless to say, developing ICT skills is beneficial to individuals after their graduation, both personally and professionally. Graduates with the ability to use IT-specific programs (Medallion PMS, Amadeus Agency Business Manager-Romania (TINA), Amadeus Internet Booking Engine, Worldspan) could quickly become employees of travel agencies or hotels in Constanta County and thus contribute to the development of the tourism industry in Romania.

In the context of sustainable tourism, using and taking advantage of information and technology are absolutely necessary skills for tourism employees. The future workforce in tourism must face the challenges brought to light by instant communication, social media and other innovative technologies.

Our study emphasized the need for change in an educational field of activity in which the training and development of employees is crucial. One of the main limitations of the study is related to the fact the experiment did not analyze the ICT-specific tools and methods that influence the educational process in tourism so much. ICT was regarded as a whole method and the results were presented as a general tendency. Moreover, the experiment was conducted only in tourism profile high-schools from Romania and did not analyze higher education institutions or other tourism-training organizations.

Further research should be considered in order to achieve more information about the influence of ICT over experiential learning and teaching. Future studies should provide a richer description of the technologies used in teaching tourism education and the specific increase in the learning outcomes using quantitative and qualitative research methods. Further research should extend the duration of such experimental studies to different generations of students in order to emphasize a longitudinal approach and the various positive and negative effects of using ICT over a longer period of time. We would also like to explore the potential flexibility of education by regrouping students based on their initial levels of knowledge or even based on their different learning curves.

Author Contributions: A.D. and E.M.D. designed the study. R.Ș.I. and C.R. conducted the literature review. E.M.D. collected the data. All the authors participated in interpreting the results and writing the paper. C.R. revised the manuscript for intellectual content. All the authors have read and approved the final manuscript.

Conflicts of Interest: The authors declare no conflict of interest. 


\section{References}

1. Lohmann, G.; Netto, A.P. Tourism Theory Concepts, Models and Systems; CABI: Boston, MA, USA, 2017.

2. Moscardo, G.; Benckendorff, P. Education for Sustainability in Tourism-A Handbook of Processes, Resources, and Strategies; Springer: Berlin/Heidelberg, Germany, 2015.

3. Sutheeshna, B.; Sitikantha, M.; Bivraj, B.P. Tourism DEvelopment Revisited; Response Books; SAGE Publications: New Delhi, India, 2008.

4. Airey, D.; Tribe, J. An International Handbook of Tourism Education; Elsevier: Oxford, UK, 2005.

5. Theobald, W. Global Tourism; Elsevier: Amsterdam, The Netherlands, 2005.

6. Farber Canziani, B.; Sönmez, S.; Hsieh, Y.; Byrd, E.T. A Learning Theory Framework for Sustainability Education in Tourism. J. Teach. Travel Tour. 2012, 12, 3-20. [CrossRef]

7. Gastelú, C.A.T.; Kiss, G.; Domínguez, A.L. ITC Integration Process in Basic Education: The Case of Veracruz City in Mexico. Procedia Soc. Behav. Sci. 2015, 176, 819-823. [CrossRef]

8. Gnoth, J.; Matteucci, X. Important Findings in Tourism Research A Phenomenological View of the Behavioural Tourism Research Literature. Int. J. Cult. Tour. Hosp. Res. 2014, 8, 3-21. [CrossRef]

9. Vinnciombe, T.; Sou, P.U.J. Market Segmentation by Expenditure: An Underutilized Methodology in Tourism Research. Tour. Rev. 2014, 69, 122-136. [CrossRef]

10. Barron, P.; Leask, A.; Fyall, A.; Barron, P.; Leask, A.; Fyall, A.; Barron, P. Engaging the Multi-Generational Workforce in Tourism and Hospitality. Tour. Rev. 2014, 69, 245-263. [CrossRef]

11. Dessler, G. Human Resource Management; Pearson Education: London, UK, 2013.

12. Wilkinson, A.; Redman, T.; Dundon, T. Contemporary Human Resource Management; Pearson Education Limited: London, UK, 2017.

13. Wikan, G.; Molster, T. Norwegian Secondary School Teachers and ICT. Eur. J. Teach. Educ. 2011, 34, $209-218$. [CrossRef]

14. Chikasa, J.; Ntuli, M.; Sundarjee, R. ICT Integration in Teaching: An Uncomfortable Zone for Teachers: A Case of Schools in Johannesburg. Educ. Chang. 2014, 18, 137-150. [CrossRef]

15. Liburd, J.J.; Christensen, I.M.F. Using Web 2.0 in Higher Tourism Education. J. Hosp. Leis. Sport Tour. Educ. 2013, 12, 99-108. [CrossRef]

16. Rambousek, V.; Štípek, J.; Procházka, J.; Wildová, R. Research on ICT Literacy Education in Primary and Lower Secondary Schools in the Czech Republic. Procedia Soc. Behav. Sci. 2014, 141, 1263-1269. [CrossRef]

17. Kršák, B.; Tobisová, A.; Sehnálková, M. Education in Information Technology as a Tool for Tourism Development. Procedia Soc. Behav. Sci. 2014, 116, 1096-1100. [CrossRef]

18. Solhaug, T. Two Configurations for Accessing Classroom Computers: Differential Impact on Students' Critical Reflections and Their Empowerment. J. Comput. Assist. Learn. 2009, 25, 411-422. [CrossRef]

19. Hatlevik, O.E.; Throndsen, I.; Loi, M.; Gudmundsdottir, G.B. Students' ICT Self-Efficacy and Computer and Information Literacy: Determinants and Relationships. Comput. Educ. 2018, 118, 107-119. [CrossRef]

20. Lynch, R.L. Corporate Strategy; Prentice Hall: Upper Saddle River, NJ, USA, 2006.

21. Baum, T.; Amoah, V.; Spivack, S. Policy Dimensions of Human Resource Management in the Tourism and Hospitality Industries. Int. J. Contemp. Hosp. Manag. 1997, 9, 221-229. [CrossRef]

22. Lucas, R. Managing Employee Relations in the Hotel and Catering Industry; Cassell: London, UK, 1995.

23. Deaconu, A.; Igreț, R.; Radu, C. No TitleThe Migration of Human Resources in Europe-An Expensive Process for the Economy of Romania. In Proceedings of the New Challenges of Economic and Business Development, Riga, Latvia, 9-11 May 2013; pp. 185-195.

24. Deaconu, A.; Radu, C.; Celărel, C. The Effects of Recent Labor Market Changes on Career Choice. In Proceedings of the 10th International Conference11: Challenges of Modern Management, Bucharest, Romania, 3-4 November 2016; pp. 144-151.

25. Chen, L.; Ng, E.; Huang, S.C.; Fang, W.T. A Self-Evaluation System of Quality Planning for Tourist Attractions in Taiwan: An Integrated AHP-Delphi Approach from Career Professionals. Sustainability 2017, 9, 1751. [CrossRef]

26. DelCampo, R. Human Resource Management Demistified; McGraw-Hill: New York, NY, USA, 2011.

27. Dedu, E.M. The Relationship between Tourism and Employment in the Tourist Sector. Manag. Chall. Contemp. Soc. Proc. 2012, 3, 121-124. 
28. Baum, T. Human Resources in Tourism: Still Waiting for Change?-A 2015 Reprise. Tour. Manag. 2015, 50, 204-212. [CrossRef]

29. Harrison, D. Tourism and the Less Developed World: Issues and Case Studies; CABI Publishing Series: Oxfordshire, UK, 2001.

30. Schermerhorn, J.R.J.; Hunt, J.G.; Osborn, R.N.; Uhl-Blen, M. Organizational Behavior; John Wiley \& Sons Inc.: Hoboken, NJ, USA, 2010.

31. Lovrentjev, S. Education of Tourist Guides: Case of Croatia. Procedia Econ. Financ. 2015, 23, 555-562. [CrossRef]

32. Li, X.P.; Joppe, M.; Meis, S.M. Human Resource Management Impacts on Labour Productivity in Tourism. Tour. Econ. 2017, 23, 1028-1041. [CrossRef]

33. Madera, J.M.; Dawson, M.; Guchait, P.; Belarmino, A.M. Strategic Human Resources Management Research in Hospitality and Tourism. Int. J. Contemp. Hosp. Manag. 2017, 29, 48-67. [CrossRef]

34. Laliberté, M. Nous Entrons Dans L'ère Des Ressources Humaines-Bilan et Défis À Relever. Téoros. Revue de Recherche en Tourisme 2006, 25, 55-57.

35. Semone, P. A Case Study: Enhancing Laos' Tourism Sector Performance through Destination Human Resource Development. Asia Pacific J. Tour. Res. 2012, 17, 164-176. [CrossRef]

36. Carlin, W.; Schaffer, M.; Seabright, P. A Minimum of Rivalry: Evidence from Transition Economies on the Importance of Competition for Innovation and Growth. Contrib. Econ. Anal. Policy 2004, 3, 1-45. [CrossRef]

37. Sivadasan, J. Barriers to Competition and Productivity: Evidence from India. BE J. Econ. Anal. Policy 2009, 9, 1-66. [CrossRef]

38. UNWTO. Tourism and the Sustainable Development Goals; UNWTO: Madrid, Spain, 2015.

39. Greinert, W.-D. European Vocational Training "Systems"-Some Thoughts on the Theoretical Context of Their Historical Development. Eur. J. Vocat. Train. 2004, 32, 18-25.

40. Heikkinen, A. Vocational Education as a "Life-Project"? Reflections from the Case of Finland. J. Eur. Ind. Train. 1997, 21, 213-219. [CrossRef]

41. Hjalager, A.M. Repairing Innovation Defectiveness in Tourism. Tour. Manag. 2002, 23, 465-474. [CrossRef]

42. Purcell, K.; Quinn, J. Exploring the Education-Employment Equation in Hospitailty Management: A Comparison of Graduate and HNDs. Int. J. Hosp. Manag. 1996, 15, 51-68. [CrossRef]

43. Kusluvan, S.; Kusluvan, Z. Perceptions and Attitudes of Undergraduate Tourism Students towards Working in the Tourism Industry in Turkey. Tour. Manag. 2000, 21, 251-269. [CrossRef]

44. Lam, T.; Xiao, H. Challenges and Constraints of Hospitality and Tourism Education in China. Int. J. Contemp. Hosp. Manag. 2000, 12, 291-295. [CrossRef]

45. Daskin, M. Tourism Students' Career Conceptions towards Service Industry Profession: A Case Study from Human Resource Perspective. Middle East J. Manag. 2016, 3, 19-33. [CrossRef]

46. Dhar, R.L. Service Quality and the Training of Employees: The Mediating Role of Organizational Commitment. Tour. Manag. 2015, 46, 419-430. [CrossRef]

47. Mayaka, M.; Akama, J.S. Systems Approach to Tourism Training and Education: The Kenyan Case Study. Tour. Manag. 2007, 28, 298-306. [CrossRef]

48. Pollock, A.; Ritchie, J.R.B. Integrated Strategy for Tourism Education/training. Ann. Tour. Res. 1990, 17, 568-585. [CrossRef]

49. Deaconu, A.; Mocanu, E.M. A Comparative Study Regarding the Vocational Education and Training in Tourism in Romania, Bulgaria and Turkey. Euromentor J. Stud. Educ. 2016, 7, 75-93.

50. Mocanu, E.M.; Deaconu, A. The Use of Information and Communication Technology (ICT) as a Teaching Method in Vocational Education and Training in Tourism. Acta Didact. Napocensia 2017, 10, 19-34. [CrossRef]

51. Sotiriadis, M.; Varvaressos, S. Crucial Role and Contribution of Human Resources in the Context of Tourism Experiences: Need for Experiential Intelligence and Skills. In Handbook of Managing and Marketing Tourism Experiences; Emerald Group Publishing Limited: West Yorkshire, UK, 2016; pp. 45-64.

52. Wu, M.-H.; Thongma, W.; Leelapattana, W.; Huang, M.-L. Impact on Hotel Employee's Green Awareness, Knowledge, and Skill on Hotel's Overall Performance. Adv. Hosp. Leis. 2017, 12, 65-81.

53. Üngüren, E.; Kaçmaz, Y.Y.; Kahveci, A. Accommodation Business Management's Attitudes towards Employees Received Vocational Tourism Education. Procedia Soc. Behav. Sci. 2015, 174, 2767-2776. [CrossRef]

54. Goia Agoston, S.; Marinaș, C.V.; Igret, R.Ș. A Plea for Quality in Internship Programmes—Evidence from the Business and Administration Students' Experience. Manag. Mark. 2017, 12, 49-60. [CrossRef] 
55. Baum, T.; Cheung, C.; Kong, H.; Kralj, A.; Mooney, S.; Thi Thanh, H.N.; Ramachandran, S.; Ružic, M.D.; Siow, M.L. Sustainability and the Tourism and Hospitality Workforce: A Thematic Analysis. Sustainability 2016, 8, 809. [CrossRef]

56. Iunius, R.F.; Cismaru, L.; Foris, D. Raising Competitiveness for Tourist Destinations through Information Technologies within the Newest Tourism Action Framework Proposed by the European Commission. Sustainability 2015, 7, 12891-12909. [CrossRef]

57. Sun, Y.; Ma, H.; Chan, E. A Model to Measure Tourist Preference toward Scenic Spots Based on Social Media Data: A Case of Dapeng in China. Sustainability 2017, 10, 43. [CrossRef]

58. Bizirgianni, I.; Dionysopoulou, P. The Influence of Tourist Trends of Youth Tourism through Social Media (SM) \& Information and Communication Technologies (ICTs). Procedia Soc. Behav. Sci. 2013, 73, 652-660. [CrossRef]

59. Fidgeon, P.R. Tourism Education and Curriculum Design: A Time for Consolidation and Review? Tour. Manag. 2010, 31, 699-723. [CrossRef]

60. Deale, C.; O'Halloran, R.; Jacques, P.; Garger, J. An Examination of Current Hospitality and Tourism Teaching Methods. J. Hosp. Tour. Educ. 2010, 22, 20-29. [CrossRef]

61. DuFour, R.; DuFour, R.; Eaker, R.; Many, T. Learning by Doing: A Handbook for Professional Learning Communities at Work. In A Practical Guide for PLC Teams and Leadership, 2nd ed.; Solution Tree Press: Bloomington, Indiana, 2010.

62. Radu, C. Action Learning and Knowledge Transfer in Business Higher Education. In Proceedings of the 7th International Conference on Business Excellence, Brasov, Romania, 12-13 October 2012; pp. 137-141.

63. Radu, C. Emotional Intelligence-How Do We Motivate Our Students? Procedia Soc. Behav. Sci. 2014, 141, 271-274. [CrossRef]

64. Gavrel, F.; Lebon, I.; Rebiere, T. Formal Education versus Learning-by-Doing: On the Labor Market Efficiency of Educational Choices. Econ. Model. 2016, 54, 545-562. [CrossRef]

65. Richardson, C.; Mishra, P. Learning Environments That Support Student Creativity: Developing the SCALE. Think. Skill Creat. 2018, 27, 45-54. [CrossRef]

66. Hales, R.; Jennings, G. Transformation for Sustainability: The Role of Complexity in Tourism Students' Understanding of Sustainable Tourism. J. Hosp. Leis. Sport Tour. Educ. 2017, 21, 185-194. [CrossRef]

67. La Guardia, D.; Gentile, M.; Dal Grande, V.; Ottaviano, S.; Allegra, M. A Game Based Learning Model for Entrepreneurship Education. Procedia Soc. Behav. Sci. 2014, 141, 195-199. [CrossRef]

68. Xu, F.; Buhalis, D.; Weber, J. Serious Games and the Gamification of Tourism. Tour. Manag. 2017, 60, $244-256$. [CrossRef]

69. Adukaite, A.; van Zyl, I.; Cantoni, L. The Role of Digital Technology in Tourism Education: A Case Study of South African Secondary Schools. J. Hosp. Leis. Sport Tour. Educ. 2016, 19, 54-65. [CrossRef]

70. Prensky, M. Digital Natives, Digital Immigrants Part 1. Horizon 2001, 9, 1-6. [CrossRef]

71. Jukes, C.; McCain, T.; Crockett, L. Understanding the Digital Generation: Teaching and Learning in the New Digital Landscape; Corwin Press: Thousand Oaks, CA, USA, 2010.

72. Kirschner, P.A.; De Bruyckere, P. The Myths of the Digital Native and the Multitasker. Teach. Teach. Educ. 2017, 67, 135-142. [CrossRef]

73. The Statistics Portal, Number of Internet Users Worldwide from 2005 to 2017 (in Millions). Available online: https:/ / www.statista.com/statistics/273018/number-of-internet-users-worldwide/ (accessed on 10 April 2018).

74. Ajjan, H.; Hartshorne, R. Investigating faculty decisions to adopt Web 2.0 technologies: Theory and empirical tests. Internet High. Educ. 2008, 11, 71-80. [CrossRef]

75. Hew, K.F; Cheung, W.S. Use of Web 2.0 technologies in K-12 and higher education: The search for evidence-based practice. Educ. Res. Rev. 2013, 9, 47-64. [CrossRef]

76. Blank, G.; Reisdorf, B. The Participatory Web. Inf. Commun. Soc. 2012, 15, 537-554. [CrossRef]

77. Arpaci, I. Antecedents and Consequences of Cloud Computing Adoption in Education to Achieve Knowledge Management. Comput. Hum. Behav. 2017, 70, 382-390. [CrossRef]

78. McLoughlin, C.; Lee, M.J.W. Personalized and Self-Regulated Learning in the Web 2.0 Era: International Exemplars of Innovative Pedagogy Using Social Software. Australas. J. Educ. Technol. 2010, 26, 28-43. [CrossRef]

79. Palaigeorgiou, G.; Grammatikopoulou, A. Benefits, Barriers and Prerequisites for Web 2.0 Learning Activities in the Classroom: The View of Greek Pioneer Teachers. Interact. Technol. Smart Educ. 2016, 13, 52-70. [CrossRef] 
80. Bennett, S.; Bishop, A.; Dalgarno, B.; Waycott, J.; Kennedy, G. Implementing Web 2.0 technologies in higher education: A collective case study. Comput. Educ. 2012, 59, 524-534. [CrossRef]

81. Bronack, S.; Riedl, R.; Tashner, J. Learning in the zone: A social constructivist framework for distance education in a 3-dimensional virtual world. Interact. Learn. Environ. 2006, 14, 3-219. [CrossRef]

82. Hew, K.F; Cheung, W.S. Use of three-dimensional (3-D) immersive virtual worlds in K-12 and higher education settings: A review of the research. Brit. J. Educ. Technol. 2010, 41, 1-33. [CrossRef]

83. Wu, Y.J.; Yuan, C.-H.; Pan, C.-I. Entrepreneurship Education: An Experimental Study with Information and Communication Technology. Sustainability 2018, 10, 691. [CrossRef]

84. Danče, S. The Influence of Using the Information and Communications Technology in Primary Education. Procedia Soc. Behav. Sci. 2010, 2, 4270-4273. [CrossRef]

(C) 2018 by the authors. Licensee MDPI, Basel, Switzerland. This article is an open access article distributed under the terms and conditions of the Creative Commons Attribution (CC BY) license (http:/ / creativecommons.org/licenses/by/4.0/). 